\title{
INSTITUTIONAL STRUCTURE IN TAX AUDIT: A CASE STUDY OF TURKEY
}

\author{
Mustafa Erkan ÜYÜMEZ ${ }^{1}$
}

\author{
Sema ÜNLÜER ${ }^{2}$
}

Ali Osman YILMAZ

\begin{abstract}
Tax audits are carried out within the structure of Tax Audit Board since 2011 as a result of the merging of the former audit units under a single umbrella. Tax audits can directly or indirectly be affected by various factors. It is necessary to identify problems related to the corporate structure in tax audits and to develop the recommendations for solution. Therefore, the main purpose of the research is to identify the issues related to the institutional structure of the tax audits system in Turkey and to propose recommentations to eliminate these problems. In order to obtain in-depth information in this context, the research was carried out by qualitative research method. Qualitative research was designed as a case study. The data were collected through semistructured interviews with 15 taxpayers, 11 accounting professionals and 17 tax inspectors. The analysis of the research data was carried out with the help of NVivo 11 Pro which is one of the computer aided qualitative data analysis program by induction analysis. The findings of the research were presented based on the research question and these findings were evaluated in the context of institutional structure in tax audit.
\end{abstract}

Keywords: Tax Audit, Qualitative Research, Interview

JEL Code: H20, M42.

\section{Introduction}

It is highly essential that taxes, which are the most fundamental source of income for the states, be collected full and correctly. Tax audit is one of the basic instruments that will ensure that this is carried out peoperly. States need an effective, efficient and dissuasive tax audit system in order to control the underground economy, ensure authenticity of the declarations, increase tax compliance of taxpayers and collect more tax revenues.

Although some improvements have been made in the Turkish tax audit structure as a result of the reorganization activities carried out in 2011, the problems in tax audits have continued multiply instead of decreasing. Therefore, there is a need to obtain in-depth knowledge in order to develop the problems and root causes of the tax audits and the suggestions for the solution of these problems.

In this context, the main purpose of the study is to identify the problems related to the institutional structure of the tax audits system and offer solutions to solve these problems. This study was carried out by qualitative research method. As part of the study, qualitative research was conducted for tax inspectors, accounting professionals (sworn financial advisors and public accountants) and taxpayers.

\footnotetext{
1 Prof. Dr., Anadolu Universty, Faculty of Economics and Administrative Sciences, Department of Public Finance, meuyumez@anadolu.edu.tr

2 Asst. Prof., Anadolu Universty, School for The Handicapped, Department of Computer Use, semaaktas@anadolu.edu.tr

3 PhD Student - Internal Auditor, Anadolu Universty, Graduate School of Social Sciences, Department of Public Finance, Social Security İnstitution, Directorate for İnternal Audit Unit, yilmazaliosman@yahoo.com
} 
In the literature, quantitative research methods are used mainly in tax topics. There are many qualitative research studies in the fields of education, sociology, psychology, politics and public administration. In-depth information obtained as a result of the use of qualitative research methods on tax topic will be presented to the tax administration, tax payers, accounting professionals and scientists.

\section{Methodology}

This section provides information about the research method.

\subsection{Research Model}

Qualitative research is a research study in which a process for realizing events and situations in a realistic and holistic manner is used by using various qualitative data collection tools (Yıldırım \& Şimşek, 2008: 39).

The qualitative research design guides the researcher through the entire research process. In the case study, the researcher focuses on a situation or situations to thoroughly understand and investigate the phenomenon (Stake 2008: 121). This research is designed as case study.

\subsection{Research Environment and Participants}

In qualitative research, purposive sampling methods are mainly used (Sönmez \& Alacapınar, 2018: 174-177).

In this study, snowball (chained) sampling method was applied. The validity and reliability committee decided that the satisfaction level of the study was reached.

Participants consisted of 17 tax inspectors working in different supervisory groups in Ankara, 11 accounting professionals ( 6 public accountants and 5 certified public accountants) and 8 taxpayers in different sectors.

\subsection{Data Collection Tools}

In the case studies, the interview is a very powerful technique used to reveal participants' experiences, perceptions and perspectives in depth (Denzin \& Lincoln, 2005: 10). Interviews may be unstructured and semi-structured (Creswell, 2009: 179, 182).

In the study, semi-structured interview data collection tools, mainly non-participatory observation, archive records and document review were utilized. During the data collection process, face-toface and e-mail interviews were conducted with the participants. Information obtained before and after the interviews were transferred to the diaries.

\subsection{Data Analysis}

Content analysis was used in analyzing of the data. The content analysis process of the qualitative data is inductive in terms of shape. In content analysis, data is explored in depth and concepts and themes are explored. In this process, certain concepts and themes are brought together and 
interpreted in a way that readers can understand. Themes can be composed of several sub-levels according to the data analyzed. The themes and sub-themes refer to a general phenomenon (Marshall \& Rossman, 2006: 156-165; Gibbs, 2008: 38, 78; Glesne, 2015: 256-268-270; Mason, 1998: 111; Yin, 2009: 126).

Content analysis was performed using the Nvivo 11 pro qualitative data analysis computer program.

\subsection{Validity and Reliability of Data}

The credibility of the research results is one of the most important criteria of scientific research. Therefore, validity and reliability are the two most commonly used criteria in research. In qualitative research, triangulation is used in realization of validity and reliability (Ünlüer, 2010: 77; Gibbs, 2008: 94). In this context, the credibility (internal validity), generalizability (external validity), consistency (internal reliability) and verifiable (external reliability) of the research is attempted to be carried out (Marshall \& Rossman, 2006: 201-203; Yıldırım \& Şimşek, 2008: 255, 259, 274; Yıldırım, 2010: 84).

Within the scope of the research, data diversification was performed by using different data collection tools from various data sources. Various measures have been taken to ensure the validity and reliability of the data. Qualitative research was conducted at all stages of the study with the approval of the validity and reliability committee, thesis monitoring committee and BAP evaluation commission.

\section{Findings}

One of the main findings within the scope of this research, is the theme named "Institutional Structure in Tax Audit". The findings in this theme will be shared.

\subsection{Monopoly and Merger in Tax Investigations}

In 2011, all the audit units were united under a single mechanism called "Tax Inspection Board (VDK)". Neverthless, a complete integration amongst tax inspection staffs has not yet been achieved. Currently, there is stilla distinction between former central and provincial inspection staffs.

In response to the single mechanism and a single title within the VDK, a number of experienced central control staff has left the board. Effective inspection power was negatively affected. Former central control staff has lost their motivation within the VDK.

In this set up, tax inspection experience, institutional accumulation and effective investigation methodology could not be fully transferred to the VDK. In addition, the audit power of the provincial organization of the Revenue Administration (GiB) has been eliminated. There is currently a gap in the provincial tax audit.

After the establishment of VDK, qualified and effective tax inspections decreased and tax inspections were transformed into fabricated audits. Thus, the efficiency and deterrence of tax reviews are questioned. 
Most tax inspectors do not have the sense of "professional belonging". There are also some problems in the supervision of tax inspectors regarding their moral and professional capabilities. Thus, the VDK has become a huge institution that is difficult to manage.

\subsection{Tax Inspectors Selection, Growth Process and Trainings}

As a result of the recruitment of a large number of tax inspectors in a short time period, the quality of the inspectors could not be maintained. This has led to a weakening of the perception of "career profession".

Due to the fact that the "fellowship system" cannot be maintained, the inspection culture, professional and ethical values cannot be fully transferred to the new inspectors. Tax inspectors who fail to have adequate profession may struggle with some problems in tax inspections.

While the "sense of professional belonging" of the former central auditors transforms the challenging qualification process into a struggle to achieve an award/goal, the "fear of being eliminated" can transform the qualification process into a "life and death war".

After the establishment of VDK, the pressure to achieve performance and fear of elimination during the qualification process can cause the psychological problems. These situations affect the inspector's self-confidence, communication and social life negatively.

\subsection{Evaluation of Performance of Tax Inspectors}

The different application of the scoring criteria used in performance measurement according to the supervisory group presidencies disrupts the work ethics among the tax inspectors. Human factor can affect the the objectivity of performance appraisal and relative equality between tax inspectors.

Performance evaluation may be insufficient to measure the quality of tax inspections and sometimes it can cause pressure on inspectors to achieve their targets.

The performance measurement does not have any criteria for tax inspectors in the group presidencies except (A) Audit Group presidency. In the current performance practice, there is no award system that promotes the quality of tax inspectors .

\subsection{Audit of Tax Inspectors}

There are two aspects of auditing tax inspectors. these are the inspection of illegal activities and audited reports.

In VDK, the control and supervision of tax inspectors cannot be handled sufficiently. In fact this is not possible to accomplish in the present chaotic environment of the VDK. As long as the professional and ethical values cannot be given to the tax inspectors sufficiently and the inspectors cannot be followed, there is no mechanism to prevent any illegal acts.

Concerning the tax examination reports, which are deemed sufficient by the report evaluation committees, decisions in the judicial process may be opposite of evaluation committes. There 
is no questioning process related to the tax examination reports which have been decide in an opposite way by the court. .Furthermore, tax technique reports, which adversely affect the image of the tax administration, are not sufficiently controlled by RDKs.

\section{Conclusion}

The effectiveness and deterrence of tax audits have critical importance for those who may behave against legislation. In 2011, some improvements have been made as a result of the merger of tax audit units under the VDK. However, a complete integration between inspectors within the VDK has not been achieved.

After the establishment of VDK, tax audits have become "fabricated inspections". Many tax inspectors have no sense of "professional belonging". Due to the lack of functioning of the fellowship system, auditing culture, professional and ethical values cannot be transferred adequately to new inspectors.

Performance practice can cause pressure on inspectors to reach their targets. There is no award system that improves the quality of tax inspectors and reviews in performance.

Inspection and supervision of inspectors cannot be made sufficiently within the VDK. There is no evaluation mechanism for the audit reports within the scope of the files decided by the courts.

The quality of the inspections should be improved by eliminating the caveats in the selection and training processes of inspectors (especially in the fellowship system). In addition, effective and efficient tax audits should be started from the fabricated investigations. The sense of professional belonging of tax inspectors should be strengthened. In order to ensure integration among tax inspectors, the implementation of performance that disrupts work ethics should be revised. Feedback should be provided for the realization of the improvements in tax audit reports that have been transferred to the judicial process.

\section{References}

Creswell, J. W. (2009). Research Design: Qualitative, Quantitative and Mixed Methods Approaches, Thousand Oaks, CA: Sage Publications Inc.

Denzin N.K. \& Lincoln, Y.S. (2005). Handbook of Qualitative Research, Thousand Oaks, CA: Sage Publications Inc.

Gibbs, G.R. (2008). Analyzing Qualitative Data, London: Sage Publications Ltd.

Glesne, C. (2015). Nitel Araştırmaya Giriş, (Çev: A. Ersoy \& P. Yalçınoğlu), 5. Printing, Ankara: Anı Publishing.

Marshall, K. \& Rossman, G.B. (2006). Designing Qualitative Research, Thousand Oaks, CA: Sage Publications Inc.

Mason, J. (1998). Qualitative Researching, London: Sage Publications Ltd.

Sönmez, V. \& Alacapınar, F.G. (2018). Örneklendirilmiş Bilimsel Araştırma Yöntemleri, 4. Printing, Ankara: Anı Publishing. 
Stake, R.E. (2008). "Qualitative Case Studies", (Ed.) N.K. Denzin \& Y.S. Lincoln, Stratgeies of Qualitative Inquiry, Thousand Oaks, CA: Sage Publications Inc, ss.435-454.

Ünlüer, S. (2010). "Examınıng The Process of Information and Communıcation Technologıes Integration at The School for The Handıcapped", (PhD Thesis), Anadolu Universty, Eskişehir.

Yıldırım, A. \& Şimşek, H. (2008). Sosyal Bilimlerde Nitel Araştırma Yöntemleri, 6. Baskı, Ankara: Seçkin Publishing.

Yıldırım, K. (2010). "Raising The Quality in Qualitative Research". Elementary Education Online, 9 (1), 79-92. 2010, http://dergipark.gov.tr/download/article-file/90795, (05.12.2016).

Yin, R. K. (2009). Case Study Research: Design and Methods, Thousand Oaks, CA: Sage Publications Inc. 